\title{
PEMANFAATAN METODE DEMONSTRASI UNTUK PENINGKATAN HASIL BELAJAR IPA TENTANG PERUBAHAN WUJUD BENDA BAGI SISWA KELAS IV DI SD INPRES 118 KLAMALU
}

\author{
ESPITA GULTOM
}

\author{
SD Inpres 118 Klamalu Kabupaten Sorong
}

\begin{abstract}
ABSTRAK
Penelitian ini bertujuan untuk mengetahui Peningkatan Hasil Belajar IPA Tentang Perubahan Wujud Benda Bagi Siswa kelas IV di SD Inpres 118 Klamalu melalui pemanfaatan Metode Demonstrasi. Jenis penelitian ini adalah penelitian tindakan kelas (Classroom Action Research) yang dilakukan secara kolaboratif antara peneliti dengan guru. Penelitian dilaksanakan dalam dua siklus, masing-masing siklus terdiri dari empat komponen yaitu perencanaan, tindakan, pengamatan dan refleksi. Teknik pengumpulan data yang digunakan dalam penelitian ini adalah wawancara, observasi, dokumentasi dan tes. Analisis data dilakukan dalam 3 tahap yaitu reduksi, penyajian data serta menarik kesimpulan. Hasil penelitian menunjukkan bahwa: (a) pemanfaatan Metode Demonstrasi dapat meningkatkan partisipasi belajar siswa. Peningkatan Meningkatkan Prestasi Belajar Siswa Tentang Konsep Listrik dapat dilihat melalui aspek mendengarkan penjelasan bagi siklus I sebesar 28,13\% meningkat menjadi sebesar 78,13\% bagi siklus II. Partisipasi dalam mencatat penjelasan siklus 1 sebesar 25\% meningkat menjadi sebesar 93,75\% bagi siklus II. Partisipasi dalam memperhatikan pembelajaran siklus I sebesar 31,25\% meningkat menjadi sebesar 90,63\% bagi siklus II. Partisipasi dalam bertanya siklus I sebesar 21,87\% meningkat menjadi sebesar 68,75\% bagi siklus II. Partisipasi dalam menjawab pertanyaan siklus I sebesar 25\% meningkat menjadi sebesar 78,13\% bagi siklus II. Partisipasi dalam mengeluarkan pendapat siklus I sebesar 28,13\% meningkat menjadi sebesar 71,87\% bagi siklus II. Partisipasi dalam menghargai pendapat teman siklus I sebesar 34,38\% meningkat menjadi sebesar 78,13\% bagi siklus II. Partisipasi dalam menjelaskan kembali siklus I sebesar 21,87\% meningkat menjadi sebesar 75\% bagi siklus II. (b) Pemanfaatan Metode Demonstrasi dapat meningkatkan prestasi belajar siswa. Rata-rata hasil belajar siswa bagi siklus I sebesar 32,19 meningkat menjadi 82,03 bagi siklus II.
\end{abstract}

Kata kunci : Demonstrasi, IPA, wujud, benda,

\begin{abstract}
This study aims to determine the Improvement of Science Learning Outcomes About Changes in Objects for Grade IV Students at SD Inpres 118 Klamalu through the use of Demonstration Methods. This type of research is a Classroom Action Research conducted collaboratively between researchers and teachers. The study was conducted in two cycles, each cycle consisting of four components, namely planning, action, observation and reflection. Data collection techniques used in this study were interviews, observation, documentation and tests. Data analysis was carried out in 3 stages namely reduction, presentation of data and drawing conclusions. The results showed that: (a) the use of the Demonstration Method can increase student learning participation. Increasing Improving Student Learning Achievement about the Concept of Electricity can be seen through the aspect of listening to explanation for the first cycle of $28.13 \%$ increased to $78.13 \%$ for the second cycle. Participation in recording cycle 1 explanation by 25\% increased to $93.75 \%$ for cycle II. Participation in paying attention to learning cycle I of 31.25\% increased to $90.63 \%$ for cycle II. Participation in asking the first cycle of $21.87 \%$ increased to $68.75 \%$ for the second cycle. Participation in answering the first cycle question by 25\% increased to $78.13 \%$ for the second cycle. Participation in issuing the first cycle of opinions of 28.13\% increased to $71.87 \%$ for the second cycle. Participation in respecting the opinions of friends in the first cycle by $34.38 \%$ increased to $78.13 \%$ for the second cycle. Participation in explaining again the first cycle of $21.87 \%$ increased to 75\% for the second cycle. (b) Utilization of the Demonstration Method can improve student learning achievement. The average student learning outcomes for the first cycle of 32.19 increased to 82.03 for the second cycle. Keywords: Demonstrations, Natural Sciences, forms, objects,
\end{abstract}

\section{PENDAHULUAN}

Mata Pelajaran IPA sesuai Permendiknas No.22 tahun 2006 tentang standar isi menyatakan bahwa mata pelajaran I PA merupakan ilmu universal yang mendasari perkembangan teknologi modern, mempunyai peran penting dalam berbagai disiplin dan memajukan daya pikir manusia. Perkembangan pesat di bidang teknologi informasi dan komunikasi dewasa ini dilandasi oleh perkembangan Ilmu Pengetahuan di bidang Pengetahuan Alam. Untuk menguasai dan mencipta teknologi di masa depan diperlukan penguasaan Ilmu Pengetahuan Alam yang kuat sejak dini.

Mata pelajaran IPA perlu diberikan kepada semua peserta didik mula dari sekolah dasar untuk membekali peserta didik dengan kemampuan berpikir logis, analitis, sistematis, kritis, dan kreatif, serta kemampuan bekerjasama. Kompetensi tersebut diperlukan agar peserta didik dapat memiliki kemampuan memperoleh, mengelola, dan memanfaatkan informasi untuk bertahan hidup bagi keadaan yang selalu berubah, tidak pasti, dan kompetitif. 
Standar kompetensi dan kompetensi dasar dalam dokumen ini disusun sebagai landasan pembelajaran untuk mengembangkan kemampuan tersebut di atas. Selain itu dimaksudkan pula untuk mengembangkan kemampuan menggunakan pembelajaran IPA dalam pemecahan masalah dan mengkomunikasikan ide atau gagasan dengan menggunakan simbol, tabel, diagram, dan media lain.

Pendekatan pemecahan masalah merupakan fokus dalam pembelajaran IPA yang mencakup masalah tertutup dengan solusi tunggal, masalah terbuka dengan solusi tidak tunggal, dan masalah dengan berbagai cara penyelesaian. Untuk meningkatkan kemampuan memecahkan masalah perlu dikembangkan keterampilan memahami masalah, membuat model matematika, menyelesaikan masalah, dan menafsirkan solusinya.

Dalam setiap kesempatan, pembelajaran matematika hendaknya dimulai dengan pengenalan masalah yang sesuai dengan situasi (contextual problem). Dengan mengajukan masalah kontekstual, peserta didik secara bertahap dibimbing untuk menguasai konsep IPA. Untuk meningkatkan keefektifan pembelajaran, sekolah diharapkan menggunakan teknologi informasi dan komunikasi seperti komputer, alat peraga, atau media lainnya.

Sekolah Dasar Inpres 118 Klamalu terletak di Jalan Lumba-lumba Kelurahan Klamasen Distrik Mariat Kabupaten Sorong. Ketuntasan Minimal untuk mata pelajaran IPA adalah 68. Penulis mulai mengajar di SD Inpres 118 Klamalu sejak tahun 1998. Oleh Kepala Sekolah di tugaskan Wali Kelas IV.

Kondisi di atas tidak seperti saat penulis sebagai Guru. Saat penulis mengajar di jumpai siswa sulit memahami tentang Perubahan Wujud Benda. Alat peraga I P A terbatas. Siswa tidak memperhatikan saat di jelaskan.

Berdasarkan uraian di atas maka penulis tertarik untuk melakukan penelitian dengan mengambil judul "Peningkatan Hasil Belajar IPA Melalui Metode Demonstrasi Bagi Siswa kelas IV di SD Inpres 118 Klamalu”. Penelitian ini bertujuan untuk mengetahui Peningkatan Hasil Belajar IPA Tentang Perubahan Wujud Benda melalui Metode Demonstrasi Bagi Siswa kelas IV di SD Inpres 118 Klamalu.

\section{METODE PENELITIAN}

Penelitian ini merupakan penelitian tindakan kelas (classroom action research), yaitu pencermatan terhadap kegiatan belajar berupa sebuah tindakan, yang sengaja dimunculkan dan terjadi dalam sebuah kelas secara bersama. Dalam pelaksanaannya peneliti dapat melakukan penelitian tindakan kelas secara mandiri ataupun kolaboratif, akan tetapi tidak boleh menghambat kegiatan utama guru dalam proses pembelajaran.

Penelitian ini dilakukan secara kolaboratif dan partisipatif. Secara partisipatif bersama-sama mitra peneliti melaksanakan penelitian ini langkah demi langkah. Selain partisipatif, peneliti dapat berkolaborasi dengan guru Standar Kompetensi
Menangani mata pelajaran IPA dengan tujuan memperbaiki kekurangan-kekurangan dalam praktik pembelajaran. Dalam penelitian tindakan kelas ini, guru bertindak sebagai pelaksana tindakan sedangkan peneliti bertindak sebagai kolaborator.

Penelitian tindakan kelas ini dilakukan oleh peneliti, mencoba menemukan suatu gagasan yang kemudian diterapkan dalam upaya perbaikan bagi praktik pembelajaran yang dilakukan. Dalam penelitian tindakan ini mencoba menerapkan variasi model pembelajaran yang baru yaitu bagi model pembelajaran menggunakan Metode Demonstrasi yang diharapkan dapat memberikan perubahan ke arah perbaikan bagi suatu proses pembelajaran.

Dalam penelitian tindakan kelas ini terdiri atas rangkaian empat kegiatan yang dilakukan dalam siklus berulang. Empat kegiatan utama yang ada bagi setiap siklus, yaitu : 1). Perencanaan (planning), yaitu persiapan yang dilakukan untuk pelaksanaan PTK. 2). Tindakan (acting), yaitu deskripsi tindakan yang akan dilakukan, skenario kerja tindakan, perbaikan kerja yang akan dilakukan dan prosedur tindakan yang diterapkan. 3). Observasi (observing), yaitu kegiatan mengamati dampak atastindakan yang dilakukan. Kegiatan ini dapat dilakukan dengan cara pengamatan, wawancara atau cara lain yang sesuai dengan data yang dibutuhkan. 5) Refleksi (reflecting), yaitu kegiatan evaluasi tentang perubahan yang terjadi atau hasil yang diperoleh atas data yang terhimpun sebagai bentuk dampak tindakan yang telah dirancang. Berdasarkan langkah ini akan dapat diketahui perubahan yang terjadi dan dapat dilakukan tindakan sehingga mampu mencapai perubahan atau mengatasi masalah secara signifikan.

Penelitian dilaksanakan di SD Inpres 118 Klamalu yang beralamat di Jalan Lumba-lumba Kelurahan Klamasen Distrik Mariat Kabupaten Sorong. Subjek dalam penelitian ini adalah siswa kelas SD Inpres 118 Klamalu.

Variabel penelitian adalah Meningkatkatkan Prestasi Belajar Siswa Tentang Perubahan Wujud Benda adalah meningkatkan keterampilan, kemampuan, pemahaman bagi siswa tentang perubahan wujud benda dalam kehidupan sehari-hari. Prestasi belajar yang dimaksud di sini adalah hasil maksimal yang telah dicapai siswa yaitu berupa kecakapan dari masing-masing siswa yang kemudian diukur dengan tes bagi standar kompetensi menangani mata pelajaran IPA. Metode demonstrasi

Teknik pengumpulan data didapat dari observasi, wawancara, Tes dan Teknik Dokumentasi.

Instrumen yang digunakan dalam penelitian ini adalah : Non tes ( Catatan Lapangan, Lembar observasi/ pengamatan, Panduan Wawancara, Dokumentasi) dan Tes

Prosedur penelitian terdiri dari Perencanaan, Tindakan, Refleksi

Peneliti merefleksi hasil observasi terhadap proses pembelajaran yang dilaksanakan guru dan siswa di dalam kelas. Adapun yang dianalisis adalah 
partisipasi aktif siswa dan prestasi belajar siswa

Partisipasi dan prestasi belajar siswa meningkat dan apabila memenuhi target berdasarkan kriteria yakni Partisipasi aktif siswa dikatakan berhasil jika partisipasi belajar $75 \%$ siswa secara aktif berperan selama proses pembelajaran berlangsung, dan prestasi belajar siswa dikatakan berhasil jika prestasi belajar 75\% siswa bagi akhir siklus telah mencapai 7,5.

\section{PEMBAHASAN}

Dari hasil pengamatan yang dilakukan oleh peneliti, prestasi belajar bagi mata pelajaran IPA siswa kelas IV di SD Inpres 118 Klamalu dikatakan rendah karena masih ada 28 siswa yang nilainya di bawah 7,0 yang merupakan Kriteria Ketuntasan Minimal (KKM) yang telah ditentukan sekolah dengan melihat hasil ulangan harian. Hasil Observasi setelah tindakan siklus 1 dan siklus 2 diperoleh seperti ditampilkan pada tabel 3.1 .

Tabel 3. 1. Hasil Observasi Partisipasi Aktif Siswa

\begin{tabular}{|l|l|l|l|l|}
\hline \multirow{2}{*}{\multicolumn{1}{|c|}{ Aspek yang diamati }} & \multicolumn{4}{|c|}{ Partisipasi Aktif } \\
\cline { 2 - 5 } & \multicolumn{2}{|c|}{ Siklus 1 } & \multicolumn{2}{c|}{ Siklus 2 } \\
\cline { 2 - 5 } & $\sum$ siswa & Persentase & $\sum$ siswa & Persentase \\
\hline Mendengarkan Penjelasan & 9 & $28,13 \%$ & 25 & $78,13 \%$ \\
\hline Mencatat penjelasan & 8 & $25 \%$ & 30 & $93,75 \%$ \\
\hline Memperhatikan pembelajaran & 10 & $31,25 \%$ & 29 & $90,63 \%$ \\
\hline Bertanya & 7 & $21,87 \%$ & 22 & $68,75 \%$ \\
\hline Menjawab pertanyaan & 8 & $25 \%$ & 25 & $78,13 \%$ \\
\hline Mengeluarkan pendapat & 9 & $28,13 \%$ & 23 & $71,87 \%$ \\
\hline Menghargai pendapat teman & 11 & $34,38 \%$ & 25 & $78,13 \%$ \\
\hline Mampu menjelaskan kembali & 7 & $21,87 \%$ & 24 & $75 \%$ \\
\hline
\end{tabular}

Dari tabel dapat diketahui bahwa pada siklus 1 siswa yang mendengarkan penjelasan sebanyak 28,13 $\%$, mencatat penjelasan $25 \%$, memperhatiakan pembelajaran $31,25 \%$, bertanya $21,87 \%$, menjawab pertanyaan $25 \%$, mengeluarkan pendapat 28,13\% menghargai pendapat teman $34,38 \%$, mampu menjelaskan kembali 21,87 \%.

Data yang diperoleh melalui tes dihitung jumlah nilai yang diperoleh masing-masing siswa dengan cara mengakumulasikan masing-masing nilai bagi setiap item soal yang dijawab siswa. Hasil perhitungannya tes ditampilkan pada Tabel 3.2.

Tabel 3.2.. Hasil Perhitungan Tes bagi Siklus 1 dan Siklus 2

\begin{tabular}{|l|l|l|l|l|l|l|}
\hline \multirow{2}{*}{ Nama Siswa } & \multicolumn{2}{|l|}{ Tes Siklus } & \multirow{2}{*}{ Nama Siswa } & \multicolumn{2}{l|}{ Tes Siklus } \\
\cline { 2 - 3 } \cline { 6 - 7 } & $\mathbf{1}$ & $\mathbf{I I}$ & & $\mathbf{1}$ & \multicolumn{1}{|c|}{ II } \\
\hline Maryu C. Yarangga & 20 & 90 & & Febiola Kendy & 50 & 75 \\
\hline Muhammad Aji & 20 & 75 & & Gloria Wanane & 20 & 60 \\
\hline Muhammad Adit & 30 & 80 & & Salmon Mokba Kaaf & 30 & 80 \\
\hline William James Marar & 20 & 80 & & Maryam Mei Howay & 20 & 75 \\
\hline Lista Mischel Dailom & 40 & 90 & & Fery Ferdi Momot & 40 & 100 \\
\hline Muhrizal G.R. Erlanda & 50 & 75 & & Jesika Yohana Bosawer & 20 & 90 \\
\hline Windi Marani & 20 & 80 & & Naldi & 80 & 80 \\
\hline Rafli Triono Prakoso & 20 & 80 & & Lamria Hutabarat & 50 & 90 \\
\hline Tiara Putri Wulandari & 40 & 80 & & Siti Hasnah & 20 & 80 \\
\hline Pandu Mustofa & 40 & 90 & & Marthen Timate & 20 & 80 \\
\hline Yudha febrian Ifabloly & 70 & 100 & & Dilan J. Lestaluhu & 40 & 90 \\
\hline Fadilah Haq & 30 & 80 & & Indra Putra Mokoagow & 10 & 80 \\
\hline Dimas Hallatu & 0 & 80 & & Muhammad Fajar & 30 & 90 \\
\hline G.N.Falentino Kirihio & 20 & 75 & & Gloria C.A. Wanane & 70 & 90 \\
\hline Abrar arifai & 70 & 60 & & Petra Malak & 50 & 60 \\
\hline Rizki Irawan & 50 & 80 & & E Nilai & 1.030 & 2.625 \\
\hline Weldiana Triani & 20 & 90 & & Rata-rata & 32,81 & 82,03 \\
\hline
\end{tabular}

Berdasarkan rata-rata siswa bagi post test 1 dapat diketahui sebesar 32,81. Hal ini menunjukkan bahwa terjadi peningkatan hasil belajar siswa setelah menggunakan Metode Demonstrasi bagi mata pelajaran IPA. Namun berdasarkan nilai siswa bagi siklus 1 di atas, kriteria keberhasilan belum tercapai, karena masih terdapat 28 siswa belum mencapai KKM, sehingga perlu dilanjutkan dengan siklus berikutnya yaitu siklus II.

Dalam pembelajaran bagi siklus 1 ini, tahap refleksi dilakukan oleh peneliti dan guru kolaborator untuk mengevaluasi hasil observasi partisipasi aktif 
siswa dan hasil dari pelaksanaan post test sebagai umpan balik setelah pembelajaran. Penggunaan metode demonstrasi meskipun belum maksimal, sebenarnya sudah menunjukkan partisipasi aktif siswa. Masih banyak siswa yang cenderung enggan untuk mengemukakan pendapat dan hal tersebut dikarenakan siswa belum terbiasa di dalam pembelajaran menggunakan metode demonstrasi, sehingga masih banyak siswa yang pasif dalam mengikuti pembelajaran.

Bagi pelaksanaan pembelajaran menggunakan metode demonstrasi untuk meningkatkan partisipasi aktif siswa bagi siklus 1 belum sepenuhnya terlaksana dengan baik. Hal ini terjadi, mungkin dikarenakan siswa masih canggung dengan pembelajaran menggunakan metode demonstrasi.

Prestasi belajar bagi siklus 1 juga belum menunjukkan hasil yang maksimal, meskipun telah banyak siswa yang memenuhi kriteria ketuntasan minimal tetapi masih ada juga siswa yang belum memenuhi.

Berdasarkan hasil refleksi tersebut, maka perlu adanya tindakan lanjutan untuk memperbaiki atau menyempurnakan pembelajaran dengan menggunakan metode demonstrasi. Dikarenakan belum tercapainya target tindakan yang diinginkan bagi pelaksanaan tindakan bagi siklus 1 , maka peneliti dan guru sepakat untuk melanjutkan tindakan bagi siklus II.

Hasil observasi siklus 2 diperoleh data yang ditampilkan pada Tabel 3.1. Dari tabel 3.1 dapat diketahui bahwa siswa yang mendengarkan penjelasan sebanyak 78,13\%, mencatat penjelasan 93,75\%, memperhatikan pembelajaran 90,63\%, bertanya $68,75 \%$, menjawab pertanyaan 78,13\%, mengeluarkan pendapat $71,87 \%$, menghargai pendapat teman $78,13 \%$, mampu menjelaskan kembali $75 \%$.

Berdasarkan rata-rata hasil belajar antara tes bagi siklus I dan siklus II (Tabel 3.2) yang diketahui bahwa bagi tes II $(82,03)$ mempunyai rata-rata lebih tinggi dibandingkan dengan rata-rata bagi tes yang dilakukan di siklus I $(32,81$. Hal ini menunjukkan adanya terjadi peningkatan bagi hasil belajar bagi siklus II dalam mata pelajaran IPA. Berdasarkan rata-rata bagi siklus II di atas, kriteria keberhasilan sudah tercapai karena lebih dari 75\% siswa telah mencapai KKM bahkan 93,75\% siswa mencapai KKM, hal ini menunjukkan adanya pencapaian tingkat keberhasilan sesuai dengan kriteria keberhasilan yang telah ditetapkan.

Tahap refleksi peneliti bersama guru mengevaluasi hasil dari tes dan observasi, dari hasil pengamatan dan refleksi di siklus II maka penerapan metode demonstrasi dapat meningkatkan partisipasi aktif dan prestasi belajar siswa. Bagi hasil partisipasi aktif siswa, siswa telah berpartisipasi secara aktif dalam pembelajaran dan keaktifan siswa bagi proses pembelajan berlangsung dapat dilihat bagi dokumentasi berupa foto-foto yang telah terlampir dalam lampiran, sedangkan bagi hasil belajar semua siswa sudah mencapai ketuntasan yang telah ditetapkan yaitu memperoleh nilai $\geq 70$ untuk masing-masing siswa bagi siklus ke II yaitu mencapai rata-rata 82,03 Jadi dari hasil pengamatan dan refleksi di siklus II penggunaan Metode Demonstrasi dapat meningkatkan partisipasi aktif dan prestasi belajar siswa. Hal ini dikarenakan dengan menggunakan IPA, siswa lebih tertarik dan mempunyai motivasi yang tinggi untuk belajar. Keunggulan yang ada perlu dipertahankan untuk mendukung peningkatan dalam penggunaan media pembelajaran selanjutnya. Sedangkan beberapa kelemahan dalam media pembelajaran audio visual perlu diperbaiki untuk pertemuan selanjutnya. Berdasarkan hasil tes dan hasil observasi dari siklus II yang telah terjadi peningkatan dari siklus I, peneliti dan guru sepakat bahwa penelitian ini tidak dilanjutkan ke siklus III.

Dalam penelitian ini, pembahasan lebih difokuskan bagi; pelaksanaan penelitian tindakan kelas menggunakan metode demonstrasi, peningkatan partisipasi aktif bagi siswa, dan peningkatan prestasi belajar siswa dalam mata pelajaran IPA.

Pelaksanaan metode demonstrasi untuk meningkatkan partisipasi aktif dan prestasi belajar siswa dilakukan dalam dua siklus dan dilaksanakan dalam empat pertemuan di kelas. Penerapan metode demonstrasi bagi siklus I dilakukan dalam dua kali pertemuan, tetapi di dalam pelaksanaannya belum tercipta peningkatan partisipasi aktif dan prestasi belajar siswa secara maksimal, maka peneliti sepakat untuk melanjutkan bagi siklus berikutnya yaitu siklus II. Siklus demi siklus terbentuk untuk memberikan perbaikan dan perbandingan di dalam pembelajaran agar partisipasi aktif dan prestasi belajar lebih meningkat sesuai dengan apa yang diharapkan peneliti.

Dari pernyataan tersebut dapat disimpulkan bahwa mata pelajaran IPA dengan menggunakan metode demonstrasi ini dapat memberi kemudahan bagi siswa dalam memahami materi yang diberikan guru. Dalam pembelajaran siklus I masih ada siswa yang kurang dapat memahami materi pelajaran, permasalahan yang diberikan oleh guru serta belum semua siswa menunjukkan partisipasi aktif selama proses pembelajaran dengan menggunakan metode demonstrasi ini. Akan tetapi setelah siklus II para siswa berangsur-angsur dapat memahami materi, serta hampir semua siswa berpartisipasi aktif selama proses pembelajaran dengan menggunakan metode demonstrasi. Untuk menilai kriteria keberhasilan prestasi belajar siswa, peneliti menggunakan kriteria ketuntasan minimal (KKM) yang ditetapkan SD Inpres 118 Klamalu Kabupaten Sorong. Dalam mengadakan penilaian peneliti mengukur keberhasilan prestasi siswa menggunakan soal setelah tindakan dilakukan.

Hasil penelitian tindakan siklus I dan II dengan penggunaan metode demonstrasi menunjukkan adanya peningkatan terhadap aktivitas belajar siswa. Peningkatan terjadi bagi observasi siklus II di mana dalam observasi ini yang diamati adalah partisipasi aktif siswa.

Berdasarkan hasil observasi yang dapat dilihat dari tabel di atas dapat dilihat adanya peningkatan frekuensi 
dari siklus I sampai ke siklus II. Setiap indikator masing-masing siklus juga mengalami peningkatan. Bagi siklus I dan siklus II peningkatan partisipasi siswa yang paling tinggi adalah mencatat penjelasan, karena terjadi peningkatan sebesar $67,87 \%$ dan peningkatan partisipasi aktif siswa yang paling rendah adalah indikator Mengeluarkan Pendapat, karena hanya terjadi peningkatan sebesar $43,75 \%$.

Jadi dapat disimpulkan bahwa dengan penggunaan metode demonstrasi dalam mata pelajaran IPA dapat meningkatkan partisipasi aktif siswa dalam proses pembelajaran. Untuk membuktikannya dapat dilihat dalam diagram berikut:

Bagi indikator mendengarkan penjelasan persentase siswa dalam kelas bagi siklus I sebesar 28,13 \% dan bagi siklus II sebesar 78,13\%. Bagi diagram di atas menunjukkan bahwa partisipasi aktif siswa untuk mendengarkan penjelasan guru dari siklus I ke siklus II persentasenya meningkat.

Bagi indikator mencatat penjelasan persentase siswa dalam kelas bagi siklus I sebesar 25,88\% dan bagi siklus II sebesar 93,75\% . bagi diagram di atas menunjukkan bahwa partisipasi siswa dari siklus I ke siklus II terjadi peningkatan persentase siswa yang sangat signifikan, karena siswa mulai dapat mengerti dan lebih mudah menangkap pembelajaran yang disampaikan menggunakan metode demonstrasi, sehingga siswa dapat mencatat inti dari penjelasan guru bagi setiap materi yang disampaikan.

Bagi indikator memperhatikan pembelajaran persentase siswa dalam kelas bagi siklus I sebesar 31,25\% dan bagi siklus II sebesar 90,63\%. Bagi diagram di atas menunjukkan bahwa terjadi peningkatan partisipasi aktif siswa untuk memperhatikan penjelasan guru dari siklus I ke siklus II, karena siswa menjadi tertarik dengan menggunakan metode demonstrasi.

Bagi indikator bertanya persentasae siswa dalam kelas bagi siklus I 25,88 \% dan bagi siklus II sebesar $87,5 \%$. Bagi diagram di atas menunjukkan bahwa partisipasi aktif siswa untuk mendengarkan penjelasan guru dari siklus I ke siklus II juga mengalami peningkatan meskipun dalam persentase yang kecil. Hal ini terjadi karena adanya keengganan dan ketakutan siswa dalam bertanya, tetapi dengan adanya perubahan media yang digunakan guru dalam mengajar sedikit banyak mengubah siswa untuk lebih aktif dalam bertanya.

Bagi indikator menjawab pertanyaan persentase siswa dalam kelas bagi siklus 1 sebesar 28,12\% dan bagi siklus II sebesar 78,13\%. Bagi diagram di atas menunjukkan bahwa partisipasi aktif siswa untuk menjawab pertanyaan dari siklus I ke siklus II persentasenya meningkat.

Bagi Indikator mengeluarkan pendapat persentase siswa dalam kelas bagi siklus I sebesar 28,13\% dan bagi siklus II sebesar 71,87\%. Bagi diagram di atas menunjukkan bahwa partisipasi aktif siswa untuk mengeluarkan pendapat dari siklus I ke siklus II persentasenya meningkat meskipun belum semua siswa dapat melakukannya.

Bagi indikator menghargai pendapat teman persentase siswa dalam kelas bagi siklus I sebesar 43,37\% dan bagi siklus II sebesar 78,13\%. Bagi diagram di atas menunjukkan bahwa partisipasi aktif siswa untuk menghargai pendapat teman dari siklus I ke siklus II persentasenya meningkat.

Bagi indikator refleksi/mampu menjelaskan kembali persentase siswa dalam kelas bagi siklus I sebesar 21,87\% dan bagi siklus II sebesar 75 \%. Bagi diagram di atas menunjukkan bahwa partisipasi aktif siswa untuk refleksi/menjelaskan kembali dari siklus I ke siklus II persentasenya meningkat.

Penilaian yang digunakan bagi setiap siklus adalah dengan menggunakan tes dan dilaksanakan bagi setiap akhir siklus dengan soal-soal yang sesuai dengan materi yang diberikan kepada siswa. Hal ini dilakukan untuk mengukur sejauh mana siswa dapat menguasai materi yang telah disampaikan menggunakan metode demonstrasi. Hasil penelitian tindakan siklus I dan II dengan penggunaan metode demonstrasi menunjukkan adanya peningkatan terhadap prestasi belajar siswa.

Dari pernyataan tersebut, dapat disimpulkan bahwa dengan menggunakan metode demonstrasi dapat menaikkan ingatan yang berarti dapat meningkatkan pestasi beajar siswa..

Setelah dilakukan penelitian yang dimulai dari tahapan siklus I, sampai bagi tahapan siklus II dapat dilihat adanya peningkatan partisipasi aktif dan prestasi belajar siswa dengan menggunakan metode demonstrasi. Berdasarkan pemaparan prestasi belajar di atas dapat diberikan penjelasan bahwa telah terjadi peningkatan prestasi belajar siswa dari siklus I mencapai rata-rata $32,19 \%$ naik menjadi rata-rata 82,03\% bagi tahap siklus II. Dari rata-rata tersebut dapat diketahui peningkatan rata-rata 49,84\% dari siklus I ke siklus II. Dapat disimpulkan bahwa dengan penggunaan metode demonstrasi bagi mata pelajaran IPA dapat meningkatkan prestasi belajar siswa.

Peningkatan prestasi belajar dapat dilihat bagi diagram sebagai berikut:

Bagi diagram di atas menunjukkan bahwa terdapat peningkatan rata-rata nilai hasil belajar dari

siklus I sebesar 1.030 sedangkan bagi siklus II meningkat menjadi sebesar 2.625 Bagi diagram di atas menunjukkan bahwa terdapat peningkatan nilai tertinggi yang diperoleh siswa dari siklus I sebesar 80 sedangkan bagi siklus II meningkat menjadi sebesar 100 Bagi diagram di atas menunjukkan bahwa terdapat peningkatan nilai terendah yang diperoleh siswa dari siklus I sebesar 20 sedangkan bagi siklus II meningkat menjadi sebesar 60 Bagi diagram di atas menunjukkan bahwa terdapat peningkatan jumlah tuntas individu atau siswa yang mencapai Kriteria Ketuntasan Minimal (KKM) dari siklus I sebesar 4 siswa sedangkan bagi siklus II meningkat menjadi sebesar 30 siswa. Bagi diagram di atas menunjukkan bahwa terdapat peningkatan persentase ketuntasan individu. Siklus I terdapat $12,5 \%$ siswa yang telah mencapai ketuntasan atau mencapai Kriteria 
Ketuntasan Minimal (KKM). Sedangkan bagi siklus II terdapat 93,75\% siswa telah mencapai KKM.

\section{KESIMPULAN}

Berdasarkan hasil analisis data dan pembahasan yang telah peneliti lakukan, aktivitas belajar siswa Siswa Siswa kelas IV di SD Inpres 118 Klamalu untuk mata pelajaran IPA, dapat ditarik kesimpulan sebagai berikut: 1. Penerapan pembelajaran dengan menggunakan metode demonstrasi dapat meningkatkan Meningkatkatkan Prestasi Belajar Siswa Tentang Konsep Listrik bagi mata pelajaran IPA siswa kelas IV dilihat dari adanya peningkatan persentase, 2. Peningkatannya dapat dilihat dari hasil observasi bagi siklus I dan siklus II. Bagi Aspek mendengarkan penjelasan siklus I sebesar 28,13 \% dan siklus II sebesar 78,13\%. Aspek mencatat penjelasan siklus 1 sebesar 25,88\% dan siklus II sebesar 93,75\%. Aspek memperhatikan pembelajaran siklus I sebesar 31,25 dan siklus II sebesar 90,63\%. Aspek bertanya siklus I sebesar 25,88 \% dan bagi siklus II sebesar 87,5\%. Aspek menjawab pertanyaan siklus I sebesar 28,12 \% dan siklus II sebesar 78,13 \%. Aspek mengeluarkan pendapat siklus I sebesar 28,13\% dan bagi siklus II sebesar 71,87\%. Aspek menghargai pendapat teman siklus I sebesar 43,37\% dan bagi siklus II sebesar 78,13 $\%$. Aspek mampu menjelaskan kembali siklus I sebesar $21,87 \%$ dan bagi siklus II sebesar 75\%. Hal ini menunjukkan bahwa terjadi peningkatan terhadap partisipasi aktif siswa bagi Standar Kompetensi Menangani IPA. 3. Metode demonstrasi juga dapat meningkatkan hasil belajar bagi mata pelajaran IPA di kelas. Peningkatan hasil belajar ini dapat dilihat dari adanya perubahan nilai rata-rata yang diperoleh siswa bagi setiap akhir siklus. Nilai rata-rata yang diperoleh siswa bagi siklus I sebesar 32,19 dan siklus II sebesar 82,03 Hal tersebut membuktikan bahwa dengan menggunakan metode demonstrasi dapat meningkatkan prestasi belajar siswa.

\section{DAFTAR PUSTAKA}

Mulyasa. (2004). Menjadi Guru professional. Bandung: PT Remaja Rosdakarya.

Nana Sudjana. (2006). Penilaian Hasil Proses Belajar Mengajar. Bandung: PT Remaja Rosdakarya.

Riduwan. (2009). Skala Pengukuran Variabel-Variabel Penelitian. Bandung: Alfabeta.

Rochiati Wiriaatmadja. (2009). Metode Penelitian Tindakan Kelas. Bandung: PT Remaja Rosdakarya.

Slameto. (2010). Belajar dan Faktor-Faktor yang Mempengaruhi. Jakarta: Rineka Cipta.

Sugihartono. (2007). Psikologi Pendidikan. Yogyakarta: UNY .Press.

Suharsimi Arikunto. (2009). Dasar-dasar Evaluasi Pendidikan (Edisi Revisi, cetakan 7). Jakarta: Bumi Aksara

Suharsimi Arikunto, dkk. (2013). Penelitian Tindakan Kelas. Jakarta : Bumi Aksara.

Sumadi Suryabrata. (2006). Psikologi Pendidikan. Jakarta: PT Raja Grafindo Persada.

Suryobroto. (1997). Proses Belajar Mengajar di Sekolah. Jakarta: PT Rineka Cipta.

Susilo. (2007). Panduan Penelitian Tindakan Kelas. Yogyakarta: Pustaka Book Publlisher. 